\title{
Grandparents Raising Grandchildren: Taking Care of Yourself ${ }^{1}$
}

Millie Ferrer-Chancy, Larry F. Forthun, and Angela Falcone ${ }^{2}$

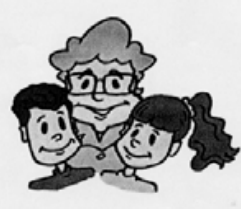

Goal: To provide grandparents raising grandchildren ways to take care of themselves

Raising your grandchild can be a difficult task, but with the appropriate coping skills, you can meet your family's needs while also maintaining your own health and well being. There are several key steps that can help: take time to relax and re-energize, recognize and share your feelings, maintain a positive outlook on life, seek support from others, and problem solve.

\section{Take Time to Relax and Re-energize}

You might be thinking that there is barely enough time to take care of your grandchildren, let alone to re-energize yourself! However, it's essential to meet your personal needs in order to handle life's challenges. Do you remember a stressful time when you were tired and overwhelmed? Most likely, you were less patient and tolerant. Perhaps using some of these coping strategies will ease some of your stress:

- find a peaceful place to relax

- take a walk

- take up a hobby

- meditate

- let go of the problem, come back to it later

- exercise, rest, and eat healthy

- $\quad$ practice stress reduction exercises

- keep a sense of humor

\section{Recognize and Share Your Feelings}

Becoming a parent again can bring lots of joy and happiness. It can also bring other feelings too. Many grandparents raising their grandchildren describe feelings of:

$$
\begin{gathered}
\text { Worry } \\
\text { Guilt } \\
\text { Anger } \\
\text { Sadness } \\
\text { Frustration }
\end{gathered}
$$

Remember that you are not alone. Other grandparents experience similar concerns. The following are some reflections by grandparents raising grandchildren.

\begin{tabular}{|} 
Grandparents' Reflections \\
"I'm grateful I'm able to provide for my \\
grandchild." \\
"I feel guilty about where I went wrong in \\
raising my own children." \\
"I'm angry that I have to change my lifestyle \\
and sacrifice personal needs and goals to care \\
for my grandchildren." \\
"I feel sad that my grandchildren have been \\
neglected." \\
"I am ashamed of my adult child's failure as a \\
parent due to alcohol and drug abuse."
\end{tabular}

1. This document, adapted from the December 2002 version of FCS2191, is FCS2191a, one of a series of the Department of Family, Youth and Community Sciences, Florida Cooperative Extension Service, Institute of Food and Agricultural Sciences (IFAS), University of Florida. Publication date: August 2009. Please visit the EDIS Web site at http://edis.ifas.ufl.edu.

2. Millie Ferrer-Chancy, Ph.D., Linterim dean, Florida Cooperative Extension Service, University of Florida; Larry F. Forthun, Ph.D., assistant professor, Department of Family, Youth and Community Sciences; Angela Falcone, former FYCS graduate student; Institute of Food and Agricultural Sciences, University of Florida, Gainesville, FL 32611 
Accepting your feelings and finding someone trustworthy to talk with will make you feel better. This can help you accept the things you cannot change.

\section{Maintain a Positive Outlook}

You have probably heard the expression; the glass is half empty or half full. How we see the glass affects our coping skills. Everything in life depends on the thoughts we choose to hold in our minds.

\begin{tabular}{|l|l|}
\hline \multicolumn{1}{|c|}{ Half-empty Glass } & \multicolumn{1}{c|}{ Half-full Glass } \\
\hline $\begin{array}{l}\text { This task is too difficult } \\
\text { for me. I give up, I feel } \\
\text { overwhelmed. }\end{array}$ & $\begin{array}{l}\text { I'll do a little each day } \\
\text { until I get it done. }\end{array}$ \\
\hline & $\begin{array}{l}\text { My grandchild is } \\
\text { curious and eager to } \\
\text { learn. I can listen a little } \\
\text { longer. Or, I can say, } \\
\text { My grandchild talks too } \\
\text { much and asks too } \\
\text { many questions. }\end{array}$ \\
$\begin{array}{l}\text { 5et's talk about that in } \\
\text { making dinner" (and } \\
\text { stick to your promise) }\end{array}$ \\
\hline $\begin{array}{l}\text { It's impossible to find } \\
\text { time for myself. }\end{array}$ & $\begin{array}{l}\text { l'll find at least 15 } \\
\text { minutes to relax today. }\end{array}$ \\
\hline
\end{tabular}

Having faith in yourself will strengthen your ability to tackle challenges. The following are some examples of seeing the glass as half-full instead of half-empty. It's important to realize that many of the skills mentioned above will be more effective if you have a positive outlook.

\section{Seek Support From Others}

All of us need and can benefit greatly from having friends, neighbors, and family to lend support. A circle of family and friends can:

- $\quad$ give encouragement

- act as a sounding board to discuss ideas and challenges

- cushion you against the stresses and strains of parenting your grandchild

- $\quad$ assist you in scheduling time for yourself

- provide additional adults who can make your grandchild feel special

So, you may ask, how can you establish a support network? For starters, you can meet people by joining a support group or starting one. For more information about starting a support group, contact AARP (see AARP Grandcare Toolkit information at the end of this publication). You can also become more involved in community, school, or religious activities. Opening yourself up to others will increase your chances of getting help. So, don't be afraid to ask others for what you need.

\section{Problem Solve}

Taking care of yourself also means taking action when there are problems. Stress builds up over time if you constantly try to avoid problems, or put off dealing with problems until later. By following these basic steps in problem solving, you will be taking the appropriate actions to resolve your problem, reduce stress, and improve well-being.

- $\quad$ Define the Problem. This may mean learning more about the problem by reading books on the topic or talking to others who are knowledgeable.

- $\quad$ Think of possible solutions. Often, there are many different ways to solve a problem. Try to identify two or three ways your problem can be resolved.

- $\quad$ Pros and Cons. Think about the pros and cons of each solution and pick the one you think is the best.

- Implement the solution. In other words, carry out your plan.

- Evaluate. Did the solution work? If not, go back to a previous solution or start the process over again.

Taking care of yourself by taking time to relax, recognizing and sharing your feelings, maintaining a positive outlook, seeking support, and problem solving will not only affect your well-being, but it will also lead to a better relationship between yourself and your grandchildren. For more information visit:

\section{AARP Grandcare Toolkit.}

http://www.aarp.org/family/grandparenting/articles Igrandcare toolkit.html

eXtension. Grandparents Raising Grandchildren. http://www.extension.org/category/family\%20care giving\%20grandparents\%20raising\%20grand children

\section{References}

Conway, F., Magai, C., Springer, C., \& Jones, S.C. (2008). Optimism and pessimism as predictors of physical and psychological health among grandmothers raising their grandchildren. Journal of Research in Personality, 42, 13521357.

Ferrer, M. (1999) Success and the single parent: Taking care of yourself. University of Florida, Cooperative Extension. 8pp. FCS 2144. 